\title{
Estratificação social e luta política no Portugal do século XIV
}

Victor Deodato da Silva

Departamento de História - FFLCH/USP

"O trabalho do historiador é forçosamente transitório em suas repercussões. Apenas a erudição é duradoura e quanto maior for a dose desta numa obra histórica, tanto melhor ela resistirá à prova do tempo" (1). Filha de seu tempo, na célebre formulação de Lucien Febvre, a "História-ciência" em suas manifestações, ou seja, nos trabalhos, acaba sendo tão fugaz na aceitabilidade de suas conclusões quanto o tempo que passa, frequentemente não tardando a se constituir sobretudo num testemunho das obsessöes e dilemas do meio e do momento que a originou. Todavia, inserida no próprio devir histórico e tendo nas informações que veicula - no caso os fatos históricos (no seu sentido mais amplo e não apenas restritos aos acontecimentos políticos), o seu material de base, a História também depende, para sua evolução e renovação, de formulações audaciosas que, ignorando as recomendações de prudência ditadas

(*) - Referência: Sérgio, Antonio, Prefácio à Crónica de D. João I, de Fernão Lopes. Porto: Civilização, 1945: XI-XL.

(1) - Talvez não rigorosamente literal, creio estar sendo fiel ao conteúdo conceitual da afirmação. Ela foi feita oralmente pelo Prof. Jean Glénisson, especialista francês em Historiografia. 
pela insuficiência de dados disponíveis, aventem hipóteses capazes de agirem como desafios, suscetíveis de abrirem novos caminhos à pesquisa.

São as chamadas "teorias" que, provocando reações às vezes violentas dos que sentem o seu referencial de compreensão do processo histórico ameaçado por especulações insatisfatoriamente fundamentadas, se revelam profícuas na medida em que mexem com as idéias feitas e estimulam revisões de posições, além de renovarem o interesse por velhos temas, que passam a ter suas perspectivas modificadas. Essas interpretações, todavia, encerram, ao lado desse influxo positivo, um aspecto que o é muito menos. Constituindo-se no fundo em hipóteses e geralmente vincadas por esquematismos deformantes, tendem essas "teorias" a serem tomadas por não poucos como verdades comprovadas e utilizadas, por sua vez, como ponto de partida para novas construções dedutivas que agravam os efeitos de seus vícios de origem. Daí a utilidade de voltar a elas periodicamente, reexaminando a solidez dos dados que as fundamentam e a compatibilidade de suas conclusões com as investigações ulteriores à elaboração na temática, que abrangem. Esses retornos, por outro lado, testemunham a sua vitalidade, visto que a ninguém interessaria deter-se em concepções notoriamente ultrapassadas.

Não cremos tenha sido publicado qualquer outro trabalho, nos últimos cinquenta anos, sobre temas históricos portugueses com repercussão comparável à do célebre "Prefácio" de Antonio Sérgio à Crónica de Dom João I de Fernão Lopes (2). As adesões à sua qualificação da crise política dos fins do século XIV como "revolução burguesa" foram numerosas e abundantes, tanto as contestações a essa tese, quanto os reparos a este ou aquele entre os argumentos que a respaldam. Não sabemos, porém, de nenhuma tentativa de um exame sistemático destes últimos, de verificação da consistência dos dados em que se apoiam e de detectação de eventuais contradições internas.

E' o que nos propomos fazer. E sem intuito polêmico, mas apenas dentro do espírito de "mise au point" (expressão para a qual fomos incapazes de encontrar um exato correspondente em português). Sem condições para fazer um levantamento exaustivo da totalidade dos trabalhos que aludem às idéias contidas no "Prefácio" (3) - o que, nesta altura

(2) - Edição da Livraria Civilização (Porto, 1945), v. 1, pp. XI-XL. Para não multiplicar desmesuradamente as notas de rodapé, limitar-nos-emos a indicar no texto, entre parênteses, a paginação das passagens referidas em nossa análise. As referências à Crônica de $D$. João I também se reportam à mesma edição ( 1 a Parte, v. 1, 1945; 2 a Parte, v. 2, 1949).

(3) - A precariedade do intercâmbio cultural entre os dois países e a situaçâo deplorável das bibliotecas brasileiras em termos de atualização do acervo têm que ser lembradas para explicar a omissão evetual de trabalhos importantes sobre a matéria. 
dos acontecimentos, já justificaria não apenas um artigo autônomo, mas mesmo uma tese historiográfica! - limitar-nos-emos, a seu tempo, às devidas referências, sempre com o intuito de concisão, quanto aos pontos, que já nos pareçam satisfatoriamente esclarecidos.

Por mais discutível que seja a sua idéia central e quão frágeis possam ser os argumentos que a fundaram, o "Prefácio" se constitui numa notável peça historiográfica. Reconhecer suas qualidades, quando estamos a ponto de examinar suas insuficiências, se torna um imperativo de justiça. De início ressalta um mérito moral: António Sérgio não se furta a informar que sua construção é hipotética. Pelo contrário, até exagera em sublinhá-lo, com expressões como "se não estou em erro", "com razão ou sem ela" ou "tudo isto é claríssimo se não vou muito em erro" (sic!), que denotam uma honestidade intelectual indiscutível. O trabalho se apresenta assim como uma provocação, um convite à revisão de posições prévias, um apelo à procura de novas perspectivas. Ele admite claramente estar fazendo conjecturas, que as pesquisas sistemáticas, então ainda por fazer, poderiam confirmar ou não.

No esforço de demonstrar a sua tese, recorre a dados de natureza variada e os entrelaça numa urdidura cerrada, na qual se sente uma obsessão totalizante, numa época em que o respeito à autonomia dos gêneros historiográficos ainda era a norma. Sobretudo num ambiente científico tradicionalista, para não dizer conformista ou retrógrado, como o dos círculos universitários portugueses de então, condicionados por censura feroz. O político, o militar, o econômico, o social, o cultural se fazem presentes, intimamente interligados. E utilizados com arte. Contrastes e transições inesperadas mantêm sempre alerta a atenção do leitor. Às vezes pressente-se um toque de prestidigitação, de ilusionismo, quando uma formulação nova e imaginosa - como a do "bando épico" (pp. XXXII e sgg.), a dar um novo e sugestivo colorido ao que, bem analisadas as coisas, não transcende às noções elementares sobre os mecanismos das relaçōes feudo-vassálicas - escondendo uma certa superficialidade de conteúdo.

Talvez essa ênfase nos valores literários choque, dando a impressão de subestimação do cunho científico do conteúdo. Todavia, retornando às nossas considerações do início, descontada a carga de erudição, de consistência informativa, o que tende a restar de todo trabalho histórico é o discurso, o testemunho de uma indagação, visto que novas pesquisas estão sempre a desatualizar a sua substância. Mesmo quando são adotadas técnicas quantitativas chega sempre o momento de explicar e então 
a linguagem do historiador se revela inevitavelmente "literária" e relevante o seu savoir faire sob esse ponto de vista formal (4). O erudito tem direito a uma postura anti-literária, à mera acumulação de dados. $\mathrm{O}$ historiador não!

Se abordarmos a questão da estrutura do Prefácio, já com vistas à apreensão de seu conteúdo, constataremos que ele tem uma tese central, que se apoia em quatro proposições básicas. Como já o dissemos, a primeira é a de que a crise portuguesa dos anos oitenta do século XIV foi eminentemente econômica e social, constituindo-se numa revoluçào burguesa e no desfecho de uma prolongada luta de classes. Inerente a esse núcleo e permeando as proposições que o sustentam, encontramos algumas idéias recorrentes, como a de que esse conflito se caracterizou pela oposição entre dois grupos: de um lado "a turba do povinho miúdo" e de outro "os aristocratas senhores rurais e a classe média dos homens-bons". Aproveitando-se desse conflito "os armadores e mercantes de Lisboa e do Pôrto, altos burgueses do comércio marítimo... se decidiu (sic!) a desencadear a insurreição política e a assumir a chefia dos negócios públicos" (p. XII, grifos de António Sérgio), naturalmente para a consecução de seus desígnios. Estes, e aqui estaria o finalismo, o ponto de convergência para todas essas oposiçōes de interesses e disputas, depois de muitas outras peripécias ulteriores ao sucesso da causa do Mestre de Avis, teriam sido atingidos e marcada "a vitória da concepção burguesa" com "a chegada do Gama a Calicute" (p. XL).

Quanto às proposições que apoiam esse núcleo, elas podem ser assim resumidas:

a) a oposição entre o "Servidor" e o "Artifice" contra o "Senhor Aristocrata" e o "Pequeno Burguês" remonta às devastações demográficas da Peste Negra de 1348;

b) a crise se precipita quando da "audaciosa abertura da guerra civil pelo Alto Burguês do comércio marítimo";

c) a vitória "burguesa" se deveu ao emprego de uma tática militar que também podemos qualificar como burguesa, caracterizada pela combinação de infantaria e arqueiros;

(4) - Bem entendido, não pretendemos legitimar um certo tipo de literatice que procura ocultar com fórmulas retóricas a ausência de conteúdo. Também não pretendemos sugerir que o historiador tenha compomissos com pesquisas estilísticas e experimentos de linguagem "per se". O elemento "literário" do historiador é mais instrumental, referindo-se à ordenação do material e a virtudes de redação, como clareza, elegância e propriedade vocabular, mas nem por isso sendo de somenos importância. 
d) pesou muito no desfecho o recurso às normas do direito romano, caracterizado pela participação de João das Regras, enteado do "chefe burguês Álvaro Paes" (p. XXV, todos os grifos e maiúsculas são de A. Sérgio).

Já se pode observar que António Sérgio tem uma forte tendência a raciocinar por arquétipos, por tipos-ideais, personalizando enfaticamente os grupos sociais, mas paradoxalmente eliminando virtualmente o indivíduo, enquanto personalidade particular da História, ou pelo menos reduzindo-o a mero exemplar característico de sua suposta "classe". Esse é um aspecto, porém, que podemos lançar à conta da "licença literária" que tanto contribui para a atração de seu trabalho e mesmo nele ver uma premonição das concepções estruturalistas muitos anos depois tão em voga. Entrando no mérito dessas idéias, examinaremos inicialmente as proposições de apoio para depois abordar a tese central.

Que a Peste Negra de 1348 tenha dado origem a sérios desequilíbrios econômicos e consideráveis tensões sociais é algo que aceitamos sem reservas. Igualmente admitimos que a legislação do trabalho por ela ocasionada - $e$ de que Portugal constitui apenas um dos exemplos (5) na Europa de então, sendo curioso que António Sérgio, sempre tão preocupado com as articulações internacionais omita o fato - contribuiu para alimentar duradouramente a hostilidade entre empregadores e empregados, tanto pelos abusos dos primeiros na aplicação das disposições régias, quanto pelo não acatamento delas da parte dos últimos.

O problema é o de avaliar o grau de ressentimento dos "miúdos", se ele efetivamente foi se intensificando a ponto de redundar na instauração de uma "atmosfera de ódios" (p. XVIII). Nos pontos da Europa onde foi possível estabelecer séries e gráficos da evolução de preços e salários observou-se uma tendência pronunciada a uma alta maior destes (6), não obstante as tentativas de contrariá-la por meios legais. Teria Portugal se constituido numa exceção? E duvidoso, já que a monarquia multiplicou medidas para remediar a crise, como a Lei das Sesmarias de 1375 e tendo em vista a ação moderadora de seus agentes no sentido de conter excessos, como o reconhece o próprio António Sérgio (p. XVII). De qualquer forma, eventos ulteriores, como as guerras de D. Fernando contra Castela, com. reflexos negativos sobre a vida econômica, tornam problemática a manutenção da vinculação direta da crise com a Peste

(5) - Para um estudo de conjunto ver DEODATO DA SILVA, V. $A$ legislação econômica e social consecutiva à Peste Negra de 1348 e sua significação no contexto da depressão da Idade Média, São Paulo, USP, 1976.

(6) - V. p. ex. ABEL, W. Agrarkrisen und Agrarkonjunktur. Berlim Hamburgo, 1966 (1a ed.: 1935), obra rica em gráficos e tabelas ilustrativos dessa tendência, com dados da mais variada procedência. 
Negra, sendo assim pouco crível que essa tensão aguardasse mais de trinta anos para explodir.

Todavia, onde nos aparece impossível acompanhar a interpretação de António Sérgio é quando ele afirma que esse ódio à classe média se manifesta, quando da crise de 1383, por ataques aos "melhores e mais honrados de cada um dos lugares" (pp. XVIII sgg. citando o Cap. XLVI da $1^{\text {a }}$. parte da Crónica de D. João I) . E isso não obstante a passagem envolver questões particularmente delicadas de nomenclatura, com estas, por sua vez, implicando problemas cruciais de estratificação social, suscetíveis por isso de conduzirem a conclusões divergentes. Antolha-se-nos por isso necessário examinar alguns aspectos genéricos, mas apesar disso fundamentais, antes de retornarmos à passagem de Fernão Lopes.

Observemos inicialmente que o cronista jamais, salvo lapso nosso, usa os termos nobre e nobreza para designar as condições sociais privilegiadas e que, como acontece geralmente com os autores do período situados fora da esfera francesa, recorre a formulas que para os ouvidos modernos soam indiretas e alusivas, apesar do emprego dos vocábulos fidalgo e barão, este rara e verossimelmente reservado a personagens merecedores de consideração especial, enquanto o primiro, muito mais frequente em suas aparições, refere-se ao conjunto da aristocracia militar e agrária. Talvez devamos, contudo, daí excluir os elementos que na França seriam incluidos na petite noblesse, para os quais é reservado o termo escudeiro.

Iríamos muito longe se nos dispuséssemos a abordar a questão da nomenclatura adotada através dos tempos para designar os segmentos sociais privilegiados (7), pelo que limitamo-nos a ressaltar que se os termos nobre e nobreza, já consagrados na França setentrional na época que nos ocupa, acabou por se impor por toda parte nos umbrais dos tempos modernos, ou seja, nos finais do século $\mathrm{XV}$, até então reinava uma prodigiosa diversidade. Além de variedade, era essa terminologia bastante instável, instabilidade essa ligada tanto às variações regionais consideráveis nas práticas sociais quanto às alterações paulatinas nelas ocorridas, embora por toda a parte hereditariedade, função social e padrão de riquezas se constituissem em parâmetros básicos da hierarquização social.

A medida que nos encaminhamos para o sul, partindo da região francesa que tem o Loire como marco meridional, o problema se compli-

(7) - Para ter uma idéia da multiformidade da questão, sugerimos duas coletâneas de artigos, a primeira reunindo apenas trabalhos do autor indicado na capa e a segunda se constituindo numa homenagem coletiva ao falecido Robert Boutruche: Duby, G. Hommes et structures du Moyen Age, Paris, 1973; Contamine, $\mathrm{Ph}$. La noblesse au Moyen Âge, Paris, 1976. 
ca pelo fato de que à nobreza propriamente dita, agrária e militar, tende a se acrescentar, como grupo dotado de forte prestígio, a camada urbana mais abastada. No contexto ibérico os homens bons, expressão também utilizada na Provença e que remonta ao direito visigodo (8), correspondiam mais ou menos aos livres ou francos das terras setentrionais, situados na fronteira que dividia a nobreza e o povo, ou àquele setor qualificado por António Sérgio de classe média. Essa expressão, já problemática quando aplicada às sociedades de nossos dias, ainda mais se revela como tal referindo-se ao século XIV. Se a admitirmos, melhores tem que forçosamente referir-se a um estrato superior, restando saber se rural ou urbano (questão que receberá novos subsídios mais adiante).

Passando ao segundo qualificativo, mais honrados, observemos que o conceito de honra, num certo sentido, resumia a essência da qualidade aristocrática, referindo-se inclusive às virtudes que se transmitiam hereditariamente (9), sendo a exclusividade reivindicada quanto à sua aplicação pela nobreza agrária e militar tradicional, contestada como veremos mais adiante, pelos segmentos urbanos mais expressivos, ou seja, a alta burguesai.

Do exposto, verifica-se que a expressão melhores e mais honrados, ou bem refere-se a nobres, ou bem a altos burgueses. No contexto em que ela surge (10), parece-nos que ela deve se aplicar aos primeiros já que, na mesma passagem, Fernão Lopes se refere aos indivíduos em causa como detentores de castelos então incendiados e forçados, por sua adesão ao legitimismo representado por Dna. Beatriz, a refugiarem-se nas terras controladas pelo rei de Castela, o que propiciou a distribuição de seus bens entre os partidários do Mestre, obedecendo ao conselho dado a este por Alvaro Paes e tão valorizado por António Sérgio: "Daae aquello que vosso nom he, e prometee o que nom teemdes, e perdoaae a quem vos nom errou..." (1 ${ }^{\mathrm{a}}$. Parte, Cap. XXVII, v. 1, p. 56).

Conclui-se, portanto, que esses conflitos e violências são essencialmente explicáveis pela excitação provocada pela perspectiva de união com Castela, que tinha no legitimismo do grosso da nobreza mais influente o seu principal pilar de sustentação e para a qual tenderam a convergir os eventuais rancores sociais reprimidos.

(8) - Wolff, Ph. "La noblesse toulousaine: essai sur son histoire médiévale", in: Contamine, La noblesse au Moyen Âge, pp. 153-174, citado às pp. 156 e 160 .

(9) - "Il suffit de considérer la conception que notre monde se fait encore aujourd'hui de la noblesse pour se convaincre que celle-ci s'est toujours fondée sur l'honneur d'une ascendence...", (Duby, "La noblesse dans la France médiévale", Hommes et structures..., p. 150).

(10) $-1^{\text {a }}$ Parte, cap. XLVI, v. 1, p. 94. 
Se é verdade que, do exposto, se pode concluir não estar caracterizada a oposição "patrão versus mão-de-obra", para a qual seria indispensável a evidência de constituirem-se os "homens bons" em alvo preferido da turba dos miúdos em seus saques e violências, nem por isso a nobreza deixaria de se constituir num obstáculo à consecução dos objetos atribuidos à burguesia. Na verdade, essa suposta animosidade contra os setores médios rurais nem chega a ser essencial à tese central de António Sérgio. Ela deriva aparentemente da preocupação de tudo explicar pelos mecanismos de luta de classe e de ver na crise a eclosão de tensões econômicas e sociais acumuladas há longo tempo. Em assim sendo, independentemente da procedência ou não desse dado, poder-se-ia mesmo assim imaginar o setor mercantil prevalecendo-se das circunstâncias políticas para alijar a nobreza do poder político. Vejamos quais os argumentos propostos no "Prefácio" em abono dessa hipótese.

"Como é óbvio, são sempre indivíduos de condição plebéia os soldados das guerras e revoluções: e não existem portanto revoluções burguesas no sentido de se constituirem com argentários de vulto as multidões combatentes com que se trava a luta" (p. XXI. desta vez o grifo é nosso). Aquilo que é aí indicado como evidente e invariável esteve muito longe de se constituir em regra, não apenas na Idade Média, mas em todo o "Antigo Regime" e em numerosos outros contextos históricos (pense-se em Esparta ou no Japão dos samurais). Combater era a função social específica dos nobres, o oposto exato de plebeus e se constituía no principal argumento para apoiar os privilégios de que eles desfrutavam na qualidade de defensores regni.Por outro lado, reduzir a burguesia a "argentários de vulto" já constitui indício de incompreensão dos mecanismos de estratificação social do período. Por último, nos pontos da Europa em que a vida urbana se mostrava mais desenvolvida - como a Itália e o Flandres - os seus exércitos, ainda que recorrendo a mercenários da mais variada origem social e étnica (na primeira mais do que no segundo citado) e ainda que não compostos exclusivamente dos referidos "argentários de vulto", recrutavam entre os cidadãos (no sentido estrito: habitantes da cidade) o grosso de suas forças, incluindo burgueses de prol (11).

Se passarmos das generalidades ao contexto ibérico veremos que, excetuada a área nordeste (a Catalunha em particular), havia uma longa

(11) - Nesse sentido, portanto, foram inequivocamente burguesas, ou citadinas, termo que confessamos preferir, as forças flamengas que derrotaram os franceses em Courtrai e massacradas em Roosebeke. Quanto aos van Artevelde, pai e filho, que exerceram comando militar além do político, não hesitamos em incluí-los entre os "argentários de vulto". 
tradição, menos observadas em áreas setentrionais, de acesso do elemento urbano às funções, e também parcialmente à honra, específica da nobreza militar, com a cavalaria vilã, que, aliás, podia ser rural ou citadina e que abriu caminho para uma "cidadania honrada" (12), sinônima, se o desejarmos, de uma honra burguesa. O critério a caracterizá-la era eminentemente econômico e político, visto que os que dela partilhavam podiam manter armamento de cavaleiro e concentravam em suas mãos o controle dos negócios municipais (às vezes dividindo-os com nobres residentes nas cidades), o que sempre constituia uma tarefa de governo e, como tal, característica do setor dominante. A parte Barcelona, caso isolado até os finais do século $\mathrm{XV}$, quando se alinhou com os demais burgos da Península, ao ver domados seus exacerbados pruridos autonomistas, os centros urbanos da região nunca gozaram da mesma força política das cidades flamengas ou das "cidades-estados" da Itália. Todavia, os seus homens de prol sempre desfrutaram de um considerável prestígio, proporcional, aliás, ao vulto dos conglomerados que dirigiam - com autonomia, frise-se, cada vez mais reduzida, à medida em que os agentes reais mais aberta e sistemáticamente interferiam nos negócios municipais - e que justifica o qualificativo de "patriciado urbano" proposto para o grupo social em causa (13).

O intuito desse grupo de, por um lado, ampliar o âmbito de sua influência e prestígio e de, por outro, consolidar franquias municipais e também conquistar novas, explica sua intensa militância política e atritos frequentes com a nobreza tradicional, agrária e militar. E útil ter-se em mente esse dado genérico ao examinar os argumentos específicos contidos no "Prefácio" para comprovar essa tese de "audaciosa abertura da guerra civil pelo Alto Burguês". Cita António Sérgio inicialmente carta de 4 de abril de 1436 de D. Duarte, relativa aos capítulos em Côrtes da cidade do Porto, enumerando as consideráveis despesas enfrentadas por essa municipalidade meio século antes, para o pagamento de homens de armas dos mais diferentes tipos (cavaleiros - isto é nobres, incluindo o Condestável - ou especialistas, arqueiros e besteiros, portugueses e ingleses), bem como de aprovisionamento de tropas (p. XXII). Em seguida, à guisa de reforço, enumera as passagens, essas abundantes, em que Fernão

(12) - Vives, V. - Historia social y económica de España y America, Barcelona, 1957, v. II, pp. $154 \mathrm{sgg.,}$ e $443 \mathrm{sgg}$. Se nos transportamos aos Países Baixos, veremos Froissart profligando como o cúmulo da empáfia burguesa a afirmação por elementos da cidade por ele citada de que "s'en tenoient les plus nobles chevaliers de Flandres à bien parés quand ils étoient bourgeois de Gand", (Chroniques, ed. Buchon, Paris, 1826, v. 7, p. 228).

(13) - Essa expressão, contudo, é estranha à terminologia da época, introduzida pelos humanistas nos finais do século XV. V. Genicot, L. Le XIIIe- siécle européen, Paris, 1968, pp. 125 sgg. 
Lopes alude à contribuição do Porto e de Lisboa para luta (pp. XXIIIXXIV).

Essas referências comprovam que os habitantes dessas duas cidades indubitávelmente se empenharam a fundo no esforço de guerra. E havia boas razões para tanto. Inicialmente, uma de ordem funcional: os militares nobres geralmente combatiam com seus próprios recursos e govazam apenas ocasionalmente do fornecimento de equipamentos, geralmente apenas de reposição em caso de perda, por parte das autoridades. Tornava-se então natural que recebessem um soldo, visto em princípio como uma indenização pelos gastos, mais do que como um ganho. Eles, além disso, pagavam o "imposto de sangue", o que justificava fossem isentos das imposiçōes fiscais, destinadas sobretudo à defesa do Reino e que recaíam então sobre os não-combatentes. Uma vez aderindo à causa do Mestre de Avis, natural era que nesse plano financeiro se concentrasse essa participação burguesa. Ou talvez fosse melhor dizer urbana, tanto mais que era notória a orientação francamente nobiliária e manifestamente hostil aos privilégios municipais do regime Trastâmara (14).

Essa motivação se torna ainda mais evidente ao considerarmos as recompensas obtidas pelos dois grandes centros urbanos, apontadas por António Sérgio, citando o cronista (p. XXIV), a saber, o alargamento dos termos de ambos e a participação, com assento à mesa de bispos e fidalgos, dos burgueses, de prol, entenda-se, do Porto, quando o já então rei $D$. João I alí casou-se. Mais significativa ainda, por se situar no plano de influxo sobre a administração do Reino é a mercê, omitida pelo "Prefácio", citada no capítulo I da $2^{\mathrm{a}}$. Parte da Crônica de D. João I (15), que trata da distribuição de funções quando da ascensão do Mestre ao trono: o direito à participação de representantes das cidades de Lisboa, Porto, Coimbra e Evora no Conselho real.

Se, destarte, está clara a participação intensa do elemento citadino em toda essa crise, bem como as retribuições de que as municipalidades foram objeto, nada indica, porém, uma reviravolta radical em termos de organização política, em função da imposição dos "planos especiais de navegação e tráfico" da burguesia ( $p$. XXVI). Além disso, deve-sẹ levar em conta a diversificação em matéria de atividades, dos homens de prol urbanos. Se é inequívoca a condição mercantil de João Ramalho, "mercador do Porto bem rrico e mui atrevudo no mar", já Alvaro Paes tinha sido chanceler de D. Fernando, portanto um burocrata a serviço da Coroa (16), praticamente assimilável nessa condição aos letrados, tendo

(14) - Russel, P. E. The English Intervention in Spain and Portugal in the time of Edward III and Richard II, Oxford, 1965, pp. 359 sgg.

(15) - 2a Parte, cap. 1, v. II, pp. 4 sgg.

p. 33 .

(16) - Serrão, Joel. o caráter social da revolução de 1383, Lisboa, 1946, 
como um dos sucessores (não imediato) o seu enteado Doutor João das Regras, nada indicando que ele tivesse participação em operações comerciais marítimas (17). A desenvoltura com que ele, na narração de Fernão Lopes, se movimenta dentro dos círculos que cercavam o Mestre de Avis já indica uma familiaridade e mesmo identificação com os grupos privilegiados.

De qualquer forma, a nos atermos ao cronista - e o "Prefácio" não indica nenhuma outra fonte que forneça dados sobre a conspiração para eliminar o Andeiro (fato precipitador da crise), Alvaro Paes é o único elemento não nobre a participar da operação que, dado muito significativo, foi precedida de tentativas anteriores, todas de fidalgos próximos à Corte. E no que tange à transformação de um problema de honra (adultério darainha) em um movimento de defesa da independência do Reino, cumpre não esquecer o papel desempenhado pela ruptura dos tratados, que regulavam a sucessão de D. Fernando, por parte de D. João I de Castela, tornando patente $o$ intuito anexionista da conduta deste, fator desencadeador dos acontecimentos muito mais evidente do que brado "Acorramos ao Mestre" de Álvaro Paes, evocado no "Prefácio".

\section{III}

Se o movimento que culminou com a substituição dinástica mobilizou todas as camadas da população - ainda que desde o início a nobreza se mostrasse dividida, já que a postura legitimista, em caso de sucesso do empreendimento castelhano, acenava com vantagens sobretudo para esse grupo - e se ele se revestiu de um cunho patriótico patente, teria ocorrido a circunstância de a vitória se dever ao "processo de oferecer combate que era próprio dos exércitos da burguesia" (p. XXVII)? Dar-se-ia o caso, porventura, de Courtrai (1302) se constituir na "primeira Aljubarrota que se viu na Europa" ou, inversamente, Aljubarrota numa Courtrai ibérica?

Os aspectos militares, das proposições de António Sérgio têm sido objeto de ampla discussão (18) e, no sentido de sua rejeição, o golpe de misericórdia foi desfechado por Gastão de Melo Matos ao demonstrar convincentemente que, mui provavelmente, em Aljubarrota não apenas os portugueses, mas também os castelhanos combateram "pé-terra" (19), situação

(17) - Alvaro Paes "incarna o burguês cujo patrimônio se não cifra na exploração da terra", informa um tanto enigmaticamente Campos Rodrigues, M. T., "PAES, Alvaro", Dicionário da História de Portugal, (dir.: Joel SERRÃO), Porto, 1971, v. 3, p. 279.

(18) - Para um levantamento crítico v. Russel, P. E. - op. cit., pp. 380 sgg.

(19) - "Consideraçôes tácticas sobre a batalha de Aljubarrota", Anais da Academia Portuguesa de História, 2a série, T. 12, 1962, pp. 11-19, sobretudo pp. 14 sgg. 
que já tinha se verificado, sem qualquer dúvida possível, num combate de menor envergadura em Trancoso pouco tempo antes, o qual, diga-se de passagem, não é objeto de qualquer referência no "Prefácio". Nessas condições, apenas na escaramuça de Atoleiros ficou caracterizada a vitória da combinação infantaria mais arqueiros contra cavalaria.

Bem mais graves do que a improcedência desse dado central são, contudo, as abundantes incoerências internas da construção interpretativa $\mathrm{e}$ as frequentes deformações históricas, em que ela assenta neste item do "Prefácio". Assim, logo no início, vem a afirmação de que, no "sentido estricto, a burguesia nasceu no Flandres" ( $p$. XXVII). Seriam os centros urbanos flamengos mais "burgueses" do que as cidades do norte da Itália? Nestas a conexão comércio-indústria estava tão presente quanto no Flandres e os italianos se notabilizaram num campo, em que seus confrades flamengos fazem pálida figura, os bancos $\mathrm{e}$ as operações financeiras. Além disso, aspecto capital para o finalismo da temática de António Sérgio - ou seja, os descobrimentos marítimos - eram os burgueses peninsulares e não os dos Países Baixos que se preocupavam mais sistematicamente em ampliar o âmbito de sua ação. Sob esse aspecto não haverá exagero em considerar o "burguesismo" flamengo bem mais medieval, isto é, voltado para si próprio, em contraste com "abertura" internacionalizante mais moderna e capitalista da Itália do Norte.

Mais adiante, somos informados de que o abastecimento flamengo de lãs na Inglaterra foi prejudicado porque "a certa altura... os insulares começaram a manufaturar eles próprios as magníficas lãs de seus carneiros... . Desenvolveu-se na Inglaterra uma mentalidade burguesa, já não só comerciante, mas industrial também, que mais tarde infligirá à aristocracia da França outras Coutrais mais rudes e mais famosas (batalha de Crecy, 1346; batalha de Poitiers, 1356)" (p. XXVII, grifo nosso). Verifica-se que, para António Sérgio que, quando da eclosão da Guerra dos Cem Anos, a indústria textil inglesa já estava instaurada, quando isso só se verificou no transcorrer da segunda metade do século XIV, em parte em decorrência da própria guerra e em parte pelo desenvolvimento da navegação atlântica $(20)$.

A burguesia inglesa assume aos poucos no "Prefácio" as conotações de uma força imperialista de atuação internacional irresistível:

"Desde que os agentes comerciais britânicos se haviam instalado no país Guiena, encontraram enfim recursos complementares que lhes

(20) - A obra clássica sobre a questão é a de Power, E. Medieval English Wool Trade, Londres, 1941. Mas esse aspecto já estava suficientemente esclarecido há algum tempo. Para citar uma obra geral, então de ampla circulação: Pirenne, H. et alii: La fin du Moyen Age en Occident (Col. "Peuples et civilisations"), V. 2, "L'annonce des temps nouveaux", Paris, 1931, pp. 148 sgg. 
não dava a Normandia, idêntica às regiões da parte sul da Inglaterra. Pelo porto de Bordéus podiam eles receber, além das lãs de Cevenas, os tintos de Toulon e os afamados vinhos de tão grande importância na alimentação dos ricos" (pp. XVII-XXVIII).

Ora, a presença inglesa na Guiena nada tinha a ver com o imperialismo burguês, era já bi-secular e não recente ("encontraram enfim"), a Inglaterra ainda era exportadora de lãs e não importadora e quanto aos vinhos, constituíam a bem dizer ingrediente na alimentação de todas as camadas sociais, embora aqui tenhamos um detalhe secundário e já por isso menos sujeito a restrições. Foram ainda, sempre segundo o "Prefácio", os "agentes comerciais ingleses" que "instigaram conflitos entre os feudais franceses e trataram de proporcionar ao seu próprio rei um solidíssimo exército de composição popular, para combater pé-terra e para atirar frechadas" (p. XXVIII). Em todo esse raciocínio a crise dinástica, devida à extinção dos Capetos de linha direta, prima pela ausência e a monarquia inglesa surge como um mero joguete da burguesia, sem interesses próprios caracterizados, enquanto os mecanismos que regiam os vínculos entre a arregimentação militar e a organização sócio-econômica aparecem fortemente distorcidos. Ao identificar a ação militar inglesa, apenas por combaterem seus exércitos "pé-terra" e com arqueiros, com os interesses da burguesia, vista então como uma espécie de "classe absoluta", de interesses idênticos por toda parte e de uma coesão que ignorava fronteiras, chegamos ao cume do contra-senso histórico ao se mostrar os burgueses franceses mancomunados com os ingleses:

“A burguesia francesa, porém, não estava tão adiantada como se achava a nossa no momento da crise de 83: e um Estevão Marcel, por esse motivo não pode ir tão longe como um Alvaro Paes. Três anos antes da revolução de Lisboa, já os Britânicos só tinham sobre o continente europeu algumas poucas cidades de ao pé da costa" p. XXVIII, grifo nosso).

É de estranhar, que imediatamente em seguida essa insinuação seja radicalmente contraditada: "e o rei da França, por seu lado, tão bem reconhecia o papel dos burgueses na obra de libertação do território pátrio que lhes outorgou em recompensa privilégios vários" (idem).

Todo esse emaranhado de contra-verdades e incoerências parece-nos resultar do "parti pris" de reduzir até às últimas consequências o processo histórico à luta de classes, ignorando os mecanismos de estratificação social do período e a. especificidade dos fenômenos políticos. No que diz respeito mais particularmente ao problema militar, ele opõe radicalmente as equações "nobreza = cavalaria = combatente montado" e "burguesia $=$ infantaria (e mais arqueiros) $=$ combatente a pé”. Ora, ocorre que, 
pelo fato de em Coutrai ter ocorrido a vitória de uma milícia burguesa, constituída basicamente por uma infantaria (com apoio, aliás, de alguns poucos cavaleiros, geralmente mercenários de origem nobre, sem a presença de arqueiros e com participação mínima apenas de besteiros) contra um exército de nobres montados, não se deve concluir que toda a força militar que combatesse a pé seria por isso burguesa e, menos ainda, que estivesse em decorrência a serviço da burguesia.

As milícias burguesas flamengas combatendo a pé conseguiram uma retumbante vitória em Courtrai (1302) e foram fragosamente derrotadas e massacradas em Roosebeke (1382); combatendo montados, os franceses foram derrotados em Crecy (1346), não tendo melhor sorte em Poitiers, apesar de fazerem-no preponderantemente a pé (1356). Quanto aos exércitos ingleses, sua espinha dorsal era constituida por nobres ou elementos comparáveis à pequena nobreza continental (21) e seus sucessos se deviam a dois fatores básicos: a eficiência dos mecanismos de conscrição e enquadramento disciplinar e à cristalização de um sistema tático, combinando não apenas cavaleiros desmontados (que geralmente recorriam aos cavalos para perseguir os inimigos quando já desbaratados ou quando se mostrasse eficaz um efeito de surpresa) e arqueiros, mas também cuidados especiais quanto à escolha do tereno de luta e um esquema de sumárias fortificações de campo (22).

Especulações têm sido feitas quanto à formação militar de Nuno Alvares Pereira (23), mas por tudo o que se sabe sobre o transcorrer de Aljubarrota, evidencia-se que os portugueses adotaram as coordenadas táticas inglesas (24). Quanto à constituição do exército luso, nobre era seu comandante e também nobres os combatentes que se constituíam no seu centro

(21) - Na verdade, o problema da nobreza se apresenta um tanto diferente na Inglaterra, em comparação com o Continente. Lá os "knights" (cavaleiros), constituiam a Gentry, distinta do baronato, estes representando a verdadeira Nobility. Para o problema de organização do exército real inglês, a obra de base é a de Powicke, M. Military Obligation in Medieval England. A Study in Liberty and Duty, Oxford, 1962.

(22) - A bibliografia a respeito é enorme. Para citar algumas obras mais correntes: Oman, Ch. A History of the Art of War in the Middle Ages, Londres, 1978 (19 ed.: 1898), V. II, p. 101 sgg.; Montross L. War through the Ages, Londres, 1944, pp. 166 sgg.

(23) - Pimenta, B. "O sistema de Nuno Alvares", Congresso do Mundo Português, V. 2, 1940, pp. 301-315, nos pinta um Condestável extremamente intelectual, conhecedor profundo de Vegécio e outros teóricos antigos da "arte da guerra", sem contudo indicar suas fontes...

(24) - Inclusive pẹla adoção, totalmente omitida por Fernão Lopes, das fortificações de campo. V. a respeito, Paço, Afonso do. "Système de fortifications de campagne découvert sur le champ de bataille d'Aljubarrota", Bulletin des Etudes Portugaises, 1963, pp. 11-24 e, sobretudo, para uma discussão sobre as condições da luta Russel, P. E. op. cit., pp. $386 \mathrm{sgg}$. 
vital, qualquer que fosse o peso tático dos arqueiros e a importância das forças auxiliares de origem burguesa ou popular. Que a maneira "nobre" de combater (baseada no guerreiro montado, pesadamente armado e atacando impeutosamente) estivesse em declínio, é algo que não pretendemos contestar, mas tal não se devia ao infante "pé-terra", apesar de sua vitória em Courtrai e dos retumbantes sucessos ulteriores dos suíços, mas sobretudo ao uso inteligente da força de tiro do conjunto dos arqueiros, mais tarde substituídos com vantagem pelos engenhos piro-balísticos e também aos aperfeiçoamentos no recrutamento e imposição de maior disciplina, transformações essas que, mais do representar a ascensão de uma classe, traduziam antes um fortalecimento incessante do Estado. $\mathrm{E}$ isso não obstante a impressão em contrário eventualmente deixada pela frequência de crises políticas no período.

\section{IV}

"Defrontavam-se duas formas de associação política: a forma $d e$ Estado e a de bando épico" (p. XXXII, grifos de A. Sérgio). Quanto à sua constituição, como já vimos, não havia grande diferença a registrar entre os exércitos português e castelhano: um núcleo de nobres, reforçado seja por especialistas de certas funções de apoio como arqueiros e besteiros, seja por tropas auxiliares de gente do povo, com os naturais de cada reino reforçados por estrangeiros, que atuavam geralmente nos dois primeiros setores, sobretudo ingleses e gascões no primeiro e preponderantemente franceses no outro. Como mais adiante António Sérgio identifica o Condestável e seus homens com o "bando épico", não seria nesse plano que se situaria o confronto em questão. Se, por outro lado, pretende o "Prefácio" que a causa da organização de Estado era defendida pelos lusos e a de bando épico pelos seus contendores, nesse caso, apesar do caráter abertamente nobiliárquico do regime Trastâmara, não cremos ser necessário gastar muitas palavras para acentuar o quanto consideramos exagerada a segunda dessas duas qualificações e exacerbando o contraste assim estabelecido entre os dois oponentes.

Se não, vejamos: para dar uma idéia do que entende por bando épico, António Sérgio evoca um romance quinhentista (que não conhecemos, confessamos lealmente, e cuja leitura não nos parece indispensável para argumentar), a Peregrinação de Fernão Mendes Pinto, que gira em torno das façanhas de uma malta de piratas liderados por António de Faria, todos fictícios, supomos. Poder-se-ia evocar igualmente o Capitão Blood e centenas de outros heróis imaginários a povoar obras em prosa e/ou verso das mais variadas épocas, sem exclusão das que têm por cenários os fantásticos tempos futuros de guerra entre estrelas, tão em moda no cinema atual. E evidente que formas rudimentares de solidariedade gru- 
pal podem surgir nos mais variados contextos - sobretudo os que envolvem alguma forma de marginalidade social - sem que elas sejam necessariamente representativas da estrutura sócio-econômica e política das sociedades, de que seus membros sejam originários, ou mesmo, a cujo serviço estejam. Em tempos recentes, a Legião Estrangeira poderia perfeitamente merecer a qualificação forjada por António Sérgio, sem que a França, beneficiária de seus serviços, deva ser por isso considerada feudal, ou algo parecido. Assim, mesmo que bandos épicos integrassem um ou ambos exércitos em luta em Aljubarrota, isso não significaria que qualquer dos reinos por eles representados se encontrasse nesse nível de organização política ou mesmo sócio-econômica.

O que se segue, já o referimos no início deste trabalho, são noções elementares a respeito das origens, princípios de funcionamento e fatores de desagregação do feudalismo, tais como as que se encontram em manuais, nível esse disfarçado pelo brilho da exposição e pela originalidade terminológica, não nos parecendo profícuo seguí-lo analíticamente neste passo. Apenas desejamos ressaltar que sentimos na exposição uma dificuldade do Autor em apoiar sua interpretação em dados específicos do contexto português no momento da crise, preferindo o terreno das generalidades. Com isso contornou ele o espinhoso problema da existência ou não de um sistema feudal no Portugal medieval (25), enquanto corpo institucional, já que relações de subordinações pessoal de fato, sobretudo em nível equiparável ao de clientela, essas sim, são facilmente detectáveis.

Retomamos o "Prefácio" quando ele enuncia o que "seria... o programa dos mercadores dos dois centros marítimos de Lisboa e do Porto": "Fazer do seu rei a encarnação de um Estado ressuscitando o direito imperial romano, e substituir o aristocrata na direcção efectiva: tal seria o caminho da revolução dos burgueses"( p. XXXVI). Defrontamo-nos em seguida com um perigoso lance dialético: "as necesidades da luta na guerra civil de então (e a crise, no essencial, pode ser considerada uma guerra civil portuguesa, com a intervenção estrangeira de $D$. João de Castela) fizeram reforçar no partido do Mestre - e sobretudo na hoste de seu condestável - o pricípio pessoalizante do bando épico" (idem). Duas flagrantes contradiçōes com pontos enfatizantes anteriormente se manifestam. Se, por um lado, o dispositivo militar português se organizava segundo os princípios do bando épico, não vemos então como ele se confundisse com uma milícia burguesa e, nesse caso, o uso da

(25) - O programa de pesquisas relativo à questão proposto por Merea, $\mathbf{M}$. P., Introdução ao problema do feudalismo em Portugal, Coimbra, 1912, ainda está por ser executado. V., porém, as considerações de Oliveira Marques, A. H., História de Portugal, Lisboa, 1975, v. 1, pp. 123 sgg. 
fórmula de combate pé-terra mais arqueiros não teve maiores conotaçōes sociológicas, sendo ditado apenas pela preocupação de eficiência. Por outro lado, no caso de "no essencial" a crise se constituir numa "guerra civil portuguesa, com... participação estrangeira", fica sériamente comprometido todo o esforço anterior no sentido de inserí-la num contexto europeu de luta de classes, de levante geral revolucionário da burguesia contra a nobreza.

Se atentarmos melhor para o que diz António Sérgio, veremos que ele acaba neste ponto de sua exposição por fornecer excelentes argumentos para a refutação de sua própria tese: o "programa" ou "plano" de Alvaro Paes na verdade nada mais representou do que um hábil estratagema, tão velho quanto a civilização, para angariar partidários, qualquer que fosse a origem social destes, ou seja, confiscar bens do adversário para premiar quem aderisse à própria causa e a servisse eficazmente. Desta forma, "a contradição com seus próprios fins, com o ideal burguês de uma sociedade de Estado" dos meios de que se serviu a revolução, somente se conretiza na medido em que se comprove a existência do objetivo indicado. Tornar-se-á necessário, em decorrência demonstrar serem os letrados legistas efetivamente os "representnates intelectuais da classe” (p. XXVII), isto é, a burguesia.

Já havia Oliveira Martins dramatizado o confronto entre o Condestável e João das Regras (26) nesse sentido e, dado o parentesco com Âlvaro Paes, a conclusẫo a que se chegar em relação a um tenderá a valer para o outro. Cremos que, ainda uma vez, a confusão esteja ligada aos diferentes sentidos de termos como burguês ou burguesia. Se com eles quisermos caracterizar a origem citadina dos letrados, legistas ou não, ou pelo menos da maior parte deles, nada haverá a objetar, já que, inclusive, era nos centros urbanos se localizavam as Universidades, onde eles se formavam. Se, porém, às expressões em causa se atribuir a conotação de pertencente aos grupos (ou "classes", se se preferir) dedicadas ao comércio e a indústria, então entrar-se-á num terreno muito mais sujeito a controvérsias. De Álvaro Paes, já o dissemos, pouco mais se sabe além do fato de que ele foi um chanceler real, um burocrata, enquanto João das Regras, graças às pesquisas de António Brásio, é bem melhor conhecido e delas ele emerge, além de servidor régio, como administrador de bens eclesiásticos e beneficiário das rendas de casas de aluguel (27), atividades completamente estranhas ao comércio ou às finanças.

(26) - A vida de Nun'Alvares: história do estabelecimento da dynastia de Aviz, Lisboa, 1917 ( $3^{a}$ ed.), pp. 361 sgg.

(27) - Brásio, A. "O Dr. João das Regras, prior da Colegiada de Santa Maria da Oliveira, de Guimarães", Anais da Academia Portuguesa de História, 2 a série, v. 23, 1975, pp. 159-170. 
Mais importante ainda, ele é sempre enumerado entre os fidalgos e qualificado como "hũ̃ notavell barom" por Fernão Lopes (28), sendo inclusive citada pelo "Prefácio" (p. XXXVII) a passagem em que o cronista fala dos "quoatro estados do Reino, que heraõ prelados e fidalgos e letrados e cidadãos" $2^{a}$. Parte, cap. I, v. II, p. 5), indicadora da assimilação dos "doutores" aos grupos privilegiados, bem como da apropriação pelos citadinos da representação destinada ao "povo" nas assembléias medievais, tendências bastante generalizadas no período. Ora, nesse contexto, equivocado seria confundir letrados e comerciantes em decorrência de sua origem urbana comum, inclusive porque todas essas condições sociais se definiam, não apenas pelas relações de função e prestígio existentes entre elas, mas também e cada vez mais pela posição, que ocupavam face à monarquia, dotada de poder crescente de mediação nas relações sociais.

E sob essa luz que nos parece dever ser considerada a hostilidade latente, destacável nas atitudes de João das Regras em relação ao Condestável em mais de uma ocasião (29) e não apenas no episódio da disputa, pelo segundo, do direito de ter vassalos. Na oportunidade teria o célebre doutor agido essencialmente como funcionário régio, guardião dos interesses da Coroa e não como porta-voz de classe. Quanto ao conflito em si, admitimos que ele ainda continua cercado de uma boa dose de obscuridade, que somente pesquisas mais sistemáticas poderão esclarecer. Aparentemente - e trata-se aqui de uma explicação provisória, de uma hipótese - Nuno Alvares Pereira, profundamente imbuído dos valores cavaleirescos e nobiliários, talvez inclusive por influência estrangeira, dados os contatos mais estreitos sobretudo com ingleses, teria desejado pôr em prática em Portugal as normas feudais tão associadas ao ditos valores, sendo normal a reação dos círculos reais, compreensivelmente ciosos em evitar o surgimento de poderes paralelos ao da côrte.

A grande dificuldade é que os procedimentos feudo-vassálicos já se encontravam em decadência e transformação por toda a Europa, sobretudo na Inglaterra, onde se desenvolvia o que os historiadores ingleses chamam de bastard feudalism, fundado nas relações de clientela e exteriorizado pelo porte de libré com emblema do superior pelos subordinados.

(28) - "... era hi huu notavell barom, homem de perfeita autoridade, e comprido de sçiençia, mui gramde leterado em lex..." (1 $1^{\text {a }}$ Parte, cap. CLXXXIII, ed. Civilização, V. I, p. 393). Já anteriormente (1a Parte, cap. XXVII, V. I, p. 55) o célebre doutor é qualificado como "mui gram leterado".

(29) - V. p. ex., 1a Parte, cap. LXXXVII, v. I, p. 166: nessa passagem João das Regras se opõe à designação de Nuno Alvares como fronteiro alegando ser para tal cargo necessário "huu homem de madura autoridade, muito avisado, e sabedor de guerra...". 
Nele, o feudo, ou seja, a terra e as cerimônias de homenagem práticamente tinham desaparecido e exatamente o que o Condestável reivindicava era o direito de ter vassalos e de entre eles distribuir terras, de conformidade com as normas feudais mais tradicionais. Todavia, devemos ter em conta que aquilo, que parece tão evidente para nós, podia sê-lo infinitamente menos para os coevos (30), podendo a iniciativa ter parecido válida ao Condestável, tanto mais que, se bem sucedida, redundaria no fortalecimento de sua posição social e política. Se adotarmos, por outro lado, a formulação de F. J. Caeiro, segundo a qual na crise todos os grupos sociais teriam prestado sua quota de serviços e depois "apresentado a conta" (31), a da parte da nobreza, que aderiu à causa do Mestre poderia ter consistido exatamente na propugnação para o grupo da liberdade de cultivar as formas de relacionamento por ele mais prezadas.

O próprio fato de essa iniciativa ter fracassado - o que não impediu o século que se sucede à crise de apresentar um perfil fortemente nobiliárquico - já é um indício de que as estruturas do estado eram suficientemente sólidas em Portugal para rejeitar a eclosão de tendências feudalizantes. E, com efeito, se alguma configuração compatível com a idéia de bando épico houve, ela foi mais aparente e ocasional do que estrutura, tanto que, uma vez proibido de ter vessalos e alegando sentir-se ferido em sua honra e planejando partir de Portugal com quem desejasse seguí-lo, Nuno Alvares renunciou ao seu projeto, visto ter muito mais a ganhar, aceitando as condições que the eram impostas. A coroa portuguesa já de há muito tinha tornado a totalidade dos nobres uma espécie de clientela sua, mediante, em primeiro lugar e mais generalizadamente, $o$ "Livro de Contias" e, em seguida e com maior discriminação, cargos administrativos na Côrte e fora dela, sinecuras e privilégios vários.

Essa tendência se insere no processo de desenvolvimento da máquina do Estado, ou melhor, na ampliação crescente dos órgãos da Coroa e longe de se atenuar:, ainda mais se intensificou com a mudança dinástica, sendo encarada como negativa em trabalho mais antigo de António Sérgio, onde se lê que a "revolução trouxe um fenômeno que se foi agravando sucessivamente: o exagero do funcionalismo, sobre tudo judicial" (32). Todavia, nociva ou não, ela era até certo ponto inevitável para o objetivo

(30) - Guenée, B. L'Occident aux XIVe et XVe siècles. Les Etats, Paris, 1971, pp. 229 sgg., mostra o considerável valor que no fim da Idade Média ainda se atribuíam aos laços feudo-vassálicos para garantir o serviço militar dos vassalos.

(31) - "Móbeis do povo português na Revolução nacional de 1383-1385", Anais da Academia Portuguesa de História, $2^{\text {a }}$ série, v. 22, 1973, pp. 11-39.

(32) - Breve interpretação da história de Portugal, Lisboa, 1972 (19a ed.: 1929), p. 40 . 
real de substituir a nobreza por seus agentes no exercício da autoridade pública. Sem dúvida, muitos dos que iam engrossar as fileiras do serviço público eram supérfluos - $\mathrm{e}$ as Cortes abundavam de queixas contra o peso que eles representavam para os cada vez mais sobrecarregados contribuintes - mas era o preço a pagar pelo fortalecimento monárquico, a compensação para a retirada das prerrogativas de exercício de justiça e outras atribuições comparáveis, de que gozavam 0 alto clero e a nobreza.

Ao agir assim, a monarquia - e aqui não nos restringimos à portuguesa - obedecia a uma dinâmica própria, independente de impulsos que pudessem partir deste ou daquele grupo social, embora sem desprezar $o$ apoio que para tanto pudesse obter nesse plano e também não deixando de recuar, quando a resistência aos avanços na imposição de sua autoridade se revelasse muito forte ou então ainda, sempre que possível, contornando-a com concessões compensatórias. Nessa faina, nenhum meio era desprezado e se o recurso às teorias de estado e às normas do direito romano tenderam a se constituir no instrumento doutrinal por excelência, já bem antes que elas atingissem aquele mínimo de difusão e também de grau de adaptação ao contexto medieval europeu de então e com isso aptas à manipulação eficaz, as próprias disposições consuetudinárias feudais foram utilizadas com vistas à centralização monárquica, como o revela o exemplo de Felipe II Augusto da França. Diríamos mesmo mais, que foi em pleno período feudal que os reis ingleses, em termos de autoridade em seu reino, se revelavam os soberanos mais poderosos da Europa, utilizando em seu proveito as relações feudovassálicos. E se eles viram a partir da Magna Carta (1215) o seu arbítrio pessoal cada vez mais limitado - num processo para o qual, frise-se, o direito romano contribuiu muito subsidiariamente - isso não implicou, muito pelo contrário, em qualquer retrocesso nas prerrogativas da Coroa, esta já vista como equivalente ao Estado na acepção romana, transcendendo aos indivíduos, mesmo ao rei.

Voltando ao "Prefácio", nele se afirma com base numa memória de 1793 (sic!), da autoria de Tomás da Vila-Nova Portugal, que "é o reinado de D. João I que devemos ter como época fixa da entrada efectiva do direito romano, porquanto só então começou ele a aplicar-se" (p. XXXVIII). Nós, com base em autoridades modernas, por nossa parte, sustentamos que o reinado de D. Dinis é que se constitui no momento decisivo a esse respeito, com a fundação da Universidade de Coimbra e a tradução das "Sete Partidas" na parte civil baseada no Código de Justiniano (33). Em termos de sua aplicação não é aventada nenhuma prova

(33) - Saraiva, A. J. História da cultura em Portugal, Lisboa, 1950, V. I, p. 280 sgg. 
documental em apoio a essa tese de primazia da nova dinastia. A argumentação de João das Regras nas. Cortes em que o Mestre de Aviz foi eleito rei (34) está inteiramente calcada em demonstrações genealógicas e o Reino, como anteriormente continuou sendo administrado pelo Rei e seu Conselho, ouvidas periodicamente as Cortes. Fala-se que "os senhores pouco se diferenciavam dos soberanos. Quando nós vemos que a um oficial de justiça que entrava a fazer uma citação ou uma penhora no seu território the cortavam os pés e o enforcavam, não acabamos de pasmar das barbaridades de tal sistema" (p. XL, citando VilaNova Portugal). Todavia, perguntamos nós, ocorriam ainda tais fatos sob D. Pedro I ou D. Fernando?

Em passagem pouco anterior António Sérgio refuta o emprego por Vila-Nova Portugal, quanto à imposição do direito romano, desses "termos de germinar, estender-se, gostar-se, (que) parecem-nos não exprimirem de todo, ainda, o condicionamento indispensável para a realização da idéia; por desgraça, tẽem sido necessários os abalos graves e a acção desagregadora das lutas armadas, que decompõem a ordem social vigente, para infundir nos homens o esforçado impulso e a indispensável coragem para as transformações profundas" (p. XXXIX). Não pretendemos negar a tendêricia de que grandes alterações, sobretudo na ordem política e institucional - e mais ainda quando ferindo sólidos interesses criados - sejam acompanhadas frequentemente de consideráveis violências, mas duvidamos que algo como a introdução de uma sistemática judiciária, e em particular o problema da adoção das normas do direito romano, não apenas em Portugal, mas em toda a Europa medieval, tenha se verificado nessas condições. Discutível se nos afigura igualmente que a generalização da obediência a essas normas constasse das obsessões dos praticantes do alto comércio, certamente já suficientemente entretidos com as preocupações inerentes a seus negócios, e, mais ainda, que coubesse à crise do fim do século XIV o papel de fazê-las passar, da noite para o dia, das especulações teóricas à aplicação prática.

Ao termo do exame das proposições que fundamentam a tese central do "Prefácio" e antes de abordá-la, enfim, queremos mais uma vez insitir em que o que nos move é o desejo de submetê-la ao crivo das aquisições que a pesquisa histórica mais recente nos oferece dentro da

(34) - Brasio, A. "A argumentação de João das Regras nas Côrtes de Coimbra em 1385", Anais da Acadmeia Portuguesa de História, 2a série, v. 10, 1961, pp. 199-233 e "Os casamentos de D. Pedro I e o Auto das Cortes de 1385", mesma publicação e volume, pp. 235-280. A própria presença do célebre Doutor nas Côrtes em questão é posta em dúvida. 
temática em discussão e de nenhuma maneira um intuito de demolição. Se é verdade que se pode arguir, que o texto de António Sérgio transmite uma sensação de obsolência maior do que alguns outros, também marcados por forte carga interpretativa - mas na verdade bem poucos, como por exemplo os clássicos $O$ declínio da Idade Média de Huizinga ou $A$ Sociedade Feudal de Marc Bloch - trabalhos de idade comparável ou mais antigos, isso se deve certamente ao fato de que nele o peso de erudição é manifestamente mais reduzido e não à insuficiência de argúcia ou carência de sensibilidade histórica. Sob esse aspecto seu ensaio se destaca no conjunto da produção histórica do período, embora acentuadamente marcado pelas idéias gerais então em voga .

Dito isto, é necessário convir, em que o apego à idéia central se revela exagerado, levando-o - queremos crer que inconscientemente e não obstante as multiplicadas precauçōes no ressaltar o hipotético de sua construção - a atribuir valor absoluto a conceitos que deveriam ser sempre $e$ sistematicamente encarados como instrumentos imperfeitos para a tentativa de apreensão e compreensão de um real fugidio em sua essência, fundamentalmente irredutível a esquemas, por mais engenhosos e perceptivos que se revelem. Insuficiente apego ao princípio da dúvida metódica, verdadeira pedra de toque do espírito científico, essa talvez seja a grande restrição a ser feita ao "Prefácio".

Todavia, se hoje a sua idéia central soa como um lugar comum historiográfico mal fundamentado, na época ela era admitida em princípio como uma sólida coordenada na compreensão do processo histórico, ao menos nos países latinos, profundamente influenciados pela cultura francesa, já que em outros meios universitários, particularmente os anglo-saxões, sempre tendeu a ser encarada com reservas. Por ela, o processo de centralização monárquica e de fortalecimento do Estado era visto como u'a mera moldura às conquistas da burguesia e à sua trajetória ascensional, tanto no plano econômico-social quanto político, culminando com a Revolução Francesa e, logicamente, procurava-se uma raiz burguesa para todos os que contribuissem para essa evolução. Aderindo a essa concepção, António Sérgio foi coerente com ela ao incorporar os descobrimentos marítimos a essa epopéia de classe, mas teve que enfrentar um sério problema: a dita idéia de ascensão burguesa comporta um inarredável ingrediente patriótico e nacional, dificilmente conciliável com a noção de uma espécie de luta de classes universal, esta por sua vez indispensável para associar a chegada do Gama a Calicute com a investida do povo de Paris contra a Bastilha. Daí as constantes hesitações e as não raras contradições.

Mais importante do que apontá-las se nos afigura ressaltar o quão problemáticas se revelam as construções históricas finalistas, quão tor- 
tuosos se mostram os processos multi-seculares, o quanto se chocam e se atropelam mútuannente os dados parciais dentro da concepção geral. Particularmente quando esta última se reveste na sua origem de um caráter nitidamente cel€bratório, fruto muito mais de uma visão entusiástica do passado à luz das conquistas de sua classe (35), do que fruto de quaisquer pesquisas sérias e como tal desprovida de real fundamento científico. Pode-se ainda perceber nessa abordagem histórica uma obsessão com a mudança e uma certa propensão a subestimar a força da inércia coletiva, sublinhando em excesso as ações e reações, e mais ainda as revoluções, quando, num exame mais acurado, observa-se que a História tende antes a constituir-se num contínuo com inflexões bruscas raras, do que numa linha constantemente quebrada por súbitas rupturas, sobretudo em épocas anteriores ao conjunto de transformações, conhecido por Revolução Industrial e nas quais o ritmo das mutações era essaz lento.

A própria idéia de revolução - com o que ela comporta de programa de transformações sociais ou políticas - era estranha ao momento histórico de que trata o "Prefácio" (36), ainda que nele abundassem crises políticas ou revoltas sociais. As consideráveis transformações que então se verificavam incidiam muito mais na direção de uma reacomodação econômica ligada às sangrias demográficas devidas às penúrias, às epidemias (com destaque especial à Peste Negra, tão realçada por António Sérgio) e outros fatores, de uma maturação do senso nacional (de que a crise portuguesa é uma excelente ilustração) e do fortalecimento da máquina do Estado (no que a nova dinastia portuguesa incrementou a ação dos últimos soberanos Borgonhas de linha legítima), muito mais do que pela revisão drástica do prestígio social e força política dos diferentes grupos sociais, especialmente na medida em que o fenômeno pudesse se medir pela ação de uns em relação aos outros e não pela posição em que eles se situassem em relação à monarquia .

Esta, vista como "aliada" da burguesia, na verdade, antes de favorecer a esta, agiu muito mais no sentido de reforçar os privilégios,

(35) - Guenée, B. op. cit., p. 80, resume bem a tese e sua origem: "La royauté, appuyée sur la bourgeoisie, triomphant de l'Église e de la noblesse, violà un des thèmes favoris des historiens français du temps de Louis-Philippe. Ce thème, qui a, plus ou moins consciemment, soustendu bien de travaux postérieurs, apparaî́t aujourd'hui bealucoup moins convaincant, en France même et surtout hors de France".

(36) - Em algumas edições consta no título do cap. $\mathrm{XX}$ do Livro $\mathrm{V}$ das Mémoires de Philippe de Commynes a expressão "révolution des estats", não usada pelo autor no texto. Mesmo que tenha sido acrescentada em data precoce, ela se refere às reviravoltas políticas atribuidas aos vícios dos governantes, provocadores da cólera divina. Trata-se de uma concepção bem conhecida daqueles familiarizados com as peças históricas de Shakespeare, pela qual a ruptura da "harmonia das esferas" provoca violentas oscilações da "roda da fortuna", o que nada tem a ver com o conceito moderno de revolução. 
consolidar a preeminência econômica e resguardar o prestígio social da nobreza, ainda que procurando esvaziar suas prerrogativas de autoridade pública e poder político. No caso específico dos descobrimentos portugueses, por sua vez, eles já tinham dado os seus primeiros passos antes da crise dos anos 80 do século XIV (37), menos por iniciativas burguesas, do que pela ação da Coroa, que continuou como a promotora principal, depois da mudança dinástica, com apoio de recursos fornecidos pela nobreza e de capitais externos, enquanto o "alto burguês comerciante de Lisboa e do Porto", que tanto interesse supostamente teria pela chegada às Indias, a ponto de desencadear uma guerra civil, teve uma participação das mais apagadas no empreendimento (38).

Logo, não é por uma explicação finalista, seja num sentido europeu, seja numa dimensão nacional, que se pode caracterizar a natureza dos acontecimentos portugueses no fím do século XIV. Não está entre nossos objetivos nesta oportunidade tratar daquilo que foi essa crise. Pensemos, contudo, em alguns aspectos de evolução ulterior de Portugal a ela ligados: a renovação aristocrática (as novas linhagens), extensiva a Castela; o florescimento das práticas e dos valores cavaleirescos, paralelo ao declínio de importância do combatente montado; a curiosa mescla de fortalecimento da Coroa e recrudescimento nobiliário; o caráter, simultâneamente conflitante e complementar, apresentado pelas cruzadas no norte da Africa e as explorações atlânticas; etc., etc. Uma vez tudo isso considerado, ainda assim, para louvar a sensibilidade de Fernão Lopes, ao proclamar o nascimento de um "outro mundo novo, muito contrário ao primeiro" (tratamento do reinado de D. Fernando), não é necessário pensarse no Novo Mundo.

O orgulho português com seus feitos ultramarinos é tão legítimo quanto o entusiasmo francês com o grau de universalidade atingido por sua Revolução, mas seria lamentável que sentimentos tão respeitáveis redundassem em fixação obsessiva com um destino manifesto. Sobretudo para a ciência histórica, pela inevitável subestimação, daí decorrente, dos problemas internos de ambas nações e a sua conexão com a respectiva evolução regional, pelas perspectivas tão ricas e tão interessantes que eles oferecem.

(37) - Serrão, J., op. cit., p. 54, já chamava a atenção para o fato de que tais expedições se iniciaram na década de 1340 , enquanto Chaunu, $\mathbf{P}$. L'expansion européene du XIII e au XVe siècle, Paris, 1969, pp. 120 sgg., insiste em que não apenas elas foram promovidas pela Coroa portuguesa, mas também em que ela não se constituiu no único poder público a fazê-lo.

(38) - Oliveira Marques, A. H. "Burguesia", Dicionário da História de Portugal (dir. Joel Serrão), Porto, 1971, v. 1, p. 396, considera praticamente nula a participação da burguesia, sobretudo a nacional. 